\title{
A clinicopathological study of nodular sclerosing Hodgkin's disease
}

\author{
R. M. CROSS \\ From the Royal Air Force Institute of Pathology and Tropical Medicine, Halton, Buckinghamshire
}

SYNOPSIS The clinicopathological features of 29 patients with nodular sclerosing Hodgkin's disease are described. The histological appearances are those of a nodular pattern due to thick fibrous bands which encircle areas of abnormal lymphoid tissue in which a particular form of abnormal reticulum cell can be recognized. They can be further subdivided into well differentiated and poorly differentiated types; the median survival time from onset in the well differentiated type was approximately nine years and in the poorly differentiated type two years. The outstanding clinical feature of patients with the well differentiated histological pattern was repeated enlargements of various groups of lymph glands over long periods of time.

In 1947 Jackson and Parker suggested that the presence of fibrosis in Hodgkin's disease might represent a favourable response on the part of the host.

Smetana and Cohen (1956) emphasized how frequently fibrosis was found in lymph glands affected by Hodgkin's disease. Their description of partial or complete fibrosis of involved glands with pseudofollicular formation and lack of SternbergReed cells closely approximated to the histological findings later described as nodular sclerosis by Lukes (1963) and Hanson (1964).

In a series of 377 patients with Hodgkin's disease discovered in United States Military personnel from 1942 to 1945 , Lukes (1963) classified $149(40 \%)$ as nodular sclerosis; he described the histological appearances and was the first to indicate the presence of a type of Sternberg-Reed cell specific for this variant of the disease. He found a high incidence of mediastinal involvement and suggested that it was a 'regional expression of Hodgkin's disease in the mediastinum'. In a large number of patients with localized manifestations the disease remained quiescent for many years but in others it became progressive with extension to the contiguous gland regions.

Hanson (1964) agreed that the nodular sclerosing type of Hodgkin's disease could be separated from Hodgkin's granuloma and found $37(15 \%)$ among 251 patients with Hodgkin's disease. He considered that the most significant findings in nodular sclerosis

Received for publication 21 August 1967. were the long survival period and the high incidence of mediastinal involvement on presentation.

There has been little mention of this variety of Hodgkin's disease in the British literature apart from the review by Harrison (1966); he, like Hanson (1964), could apply the diagnosis of nodular sclerosis only to $15 \%$ of his cases.

The purpose of the present paper is to evaluate the histological criteria, the clinical presentation, and the prognostic significance of nodular sclerosis in a relatively young population.

\section{MATERIAL AND METHODS}

The data in this paper are based on 242 cases of Hodgkin's disease presenting between 1940 and 1966 and reviewed in the histopathology centre of the Royal Air Force Institute of Pathology and Tropical Medicine, Halton. Patients were either serving in a military force, were service dependants, or were retired. Twenty-nine $(12 \%)$ of the 242 patients with Hodgkin's disease were diagnosed as cases of nodular sclerosis on histological grounds; the majority of diagnoses were made on retrospective analysis of the biopsy material.

Twenty-five of those diagnosed as nodular sclerosis were examined by means of a single biopsy and, in four, multiple biopsies were carried out. Fifteen patients were examined at necropsy as well as by biopsy.

Staining techniques were confined to haematoxylin and eosin and reticulin staining.

Clinical records were available for study in the 29 patients; clinical staging was recorded by the method of Peters and Middlemiss (1958), based on the distribution of enlarged glands at presentation of the illness. Survival 
time was estimated from the date of first admission to hospital; biopsy usually followed a few days later.

\section{HISTOLOGICAL APPEARANCES OF NODULAR SCLEROSING HODGKIN'S DISEASE}

The criteria for histological diagnosis of nodular sclerosis were as follows:-

1 The presence of classical Sternberg-Reed cells (Fig. 1) as described by Smetana and Cohen (1956).

2 The presence of abnormal reticulum cells among which were cells considered to be specific for nodular sclerosis (Fig. 2).

3 The presence of fibrosis found very often around blood vessels (Fig. 3A) but characteristically in the form of interconnecting bands of dense fibrous tissue which encircled nodules of abnormal lymphoid tissue (Fig. 3B).

Fibrosis and abnormal reticulum cells were the most relevant factors in the diagnosis of nodular sclerosis.

ABNORMAL RETICULUM CELlS In all 29 patients there were abnormal reticulum cells considered to be a characteristic feature of nodular sclerosis. These cells ranged from 40 to $50 \mu$ in diameter; the cytoplasm was abundant, pale staining and tended to shrink during processing, leaving the cell in a lacuna. The nuclear membrane was sharply defined and characteristically showed infoldings with an irregular multilobed appearance. The chromatin pattern was fine and the nucleolus tended to be small and inconspicuous (Fig. 2).

FIBRosis In two patients fibrosis in the gland was moderate and appeared as fine strands running throughout the gland. The capsule at most was only slightly thickened (Fig. 4); thus a nodular appearance was not always obvious. Subsequent biopsies of glands in these two patients, taken during the course of the illness, showed a typical nodular pattern.

In 19 patients the lymph glands at presentation showed gross thickening of the capsule with irregular shaped, occasionally rounded, nodules of abnormal lymphoid tissue surrounded by interconnecting bands of dense fibrous tissue (Fig. 6A). The nodules thus formed varied considerably in size from $0.25 \mathrm{~mm}$ to $3 \mathrm{~mm}$.

In eight patients fibrosis was much more irregular; it was sometimes arranged in large sheets but in places the nodular pattern was still retained.

The three diagnostic criteria, already described, and, in particular, the relative numbers of mature lymphocytes and the degree of anaplasia of the reticulum cells allowed subdivision of nodular sclerosis into two types: (a) well differentiated and (b) poorly differentiated.

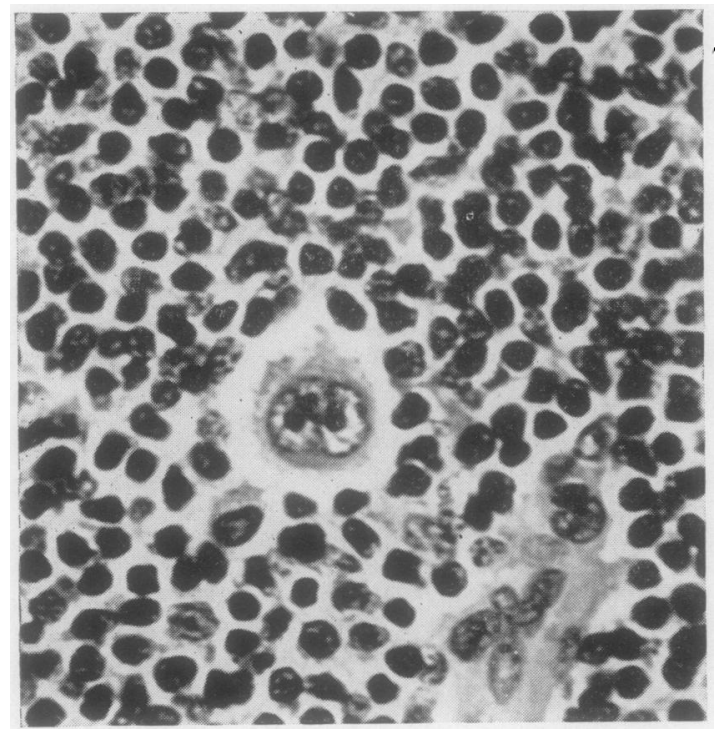

FIG. 1.

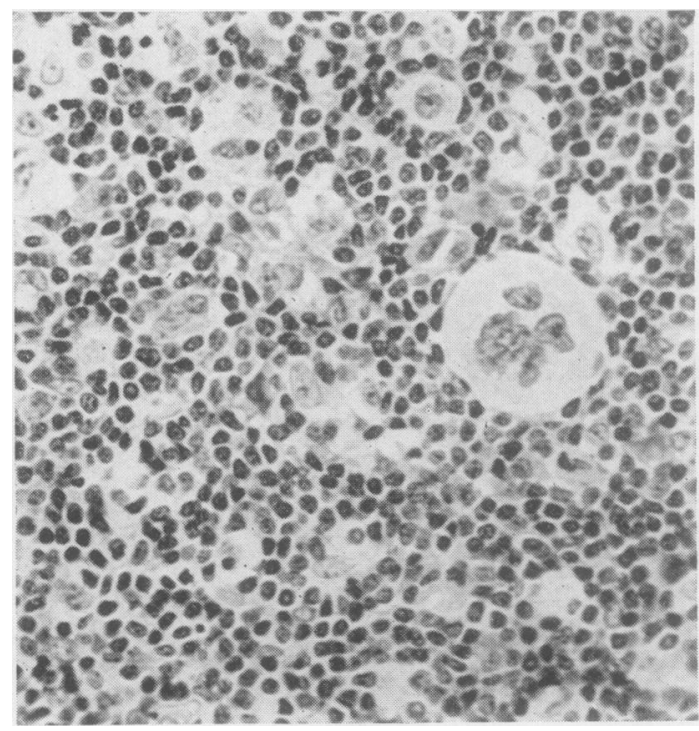

FIG. 2.

FIG. 1. Hodgkin's disease, showing the classical binucleate Sternberg-Reed cell (haematoxylin and eosin $\times 400$ ). FIG. 2. Nodular sclerosis showing the characteristic abnormal reticulum cell with infolded multilobed nucleus (haematoxylin and eosin $\times 200$ ). 

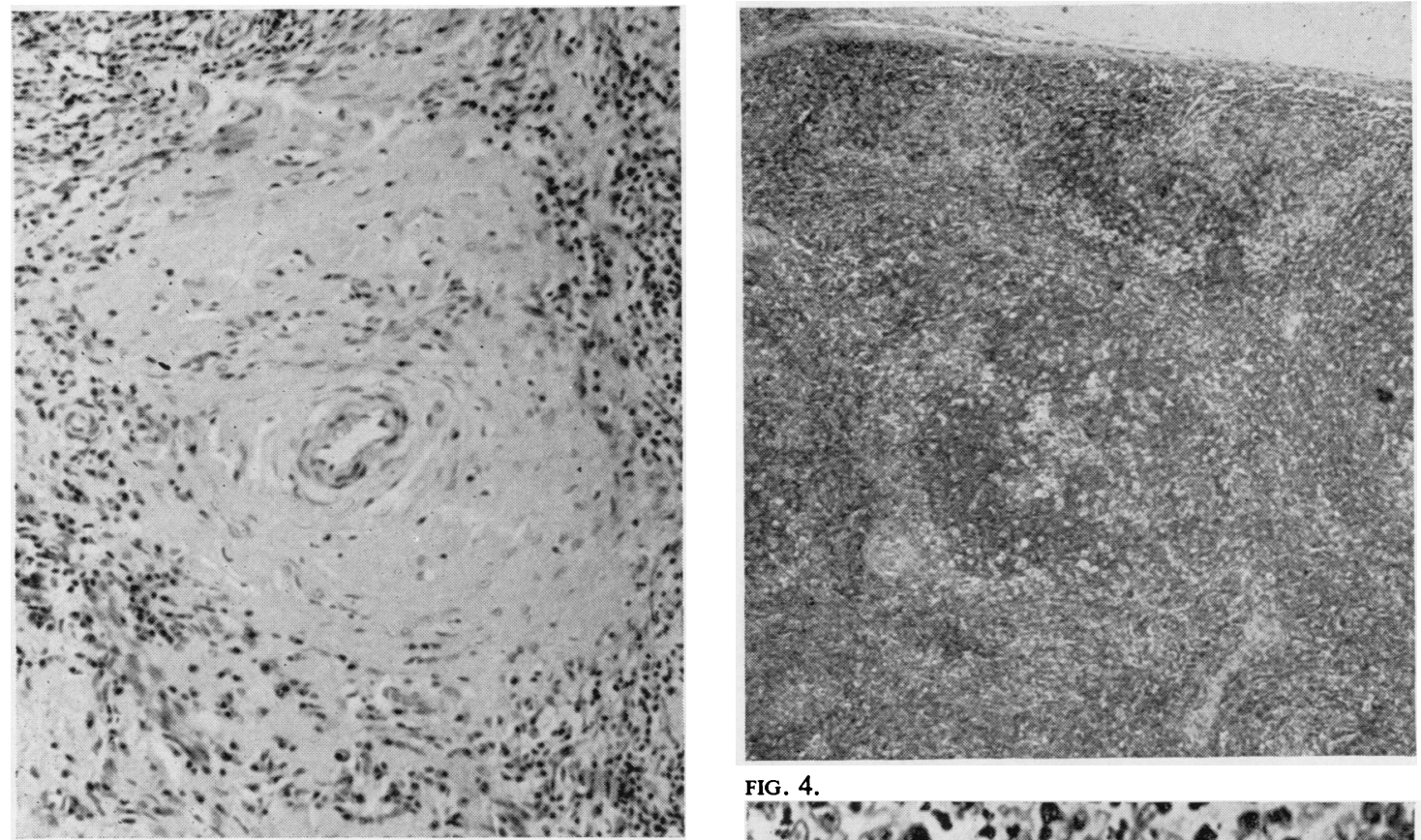

FIG. 4.

FIG. 3A.

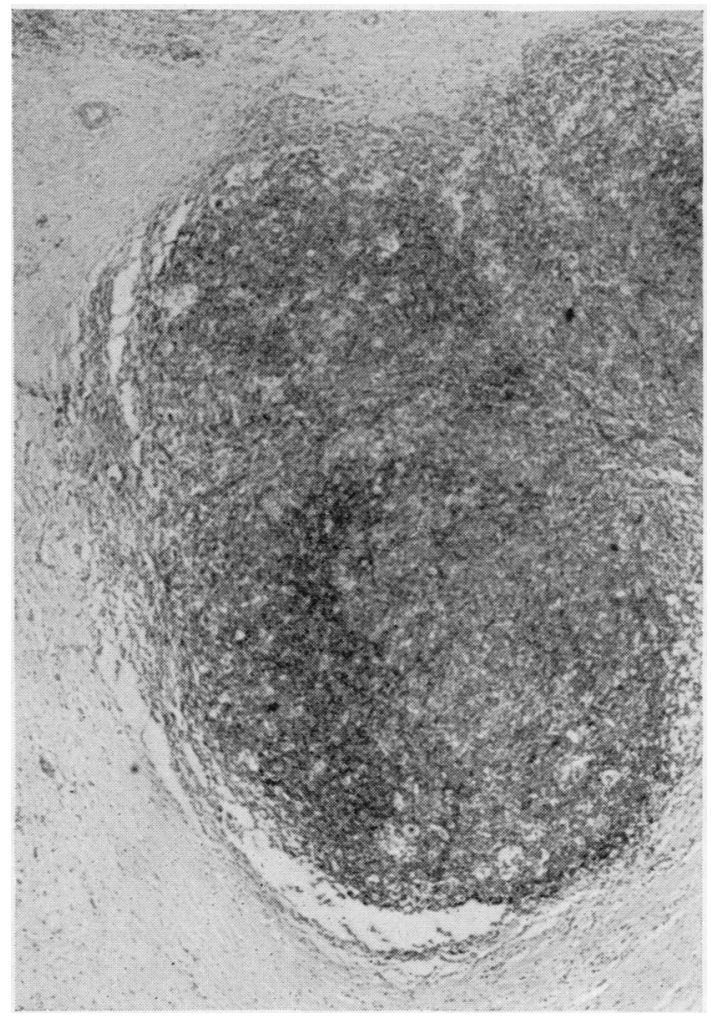

FIG. 3B.

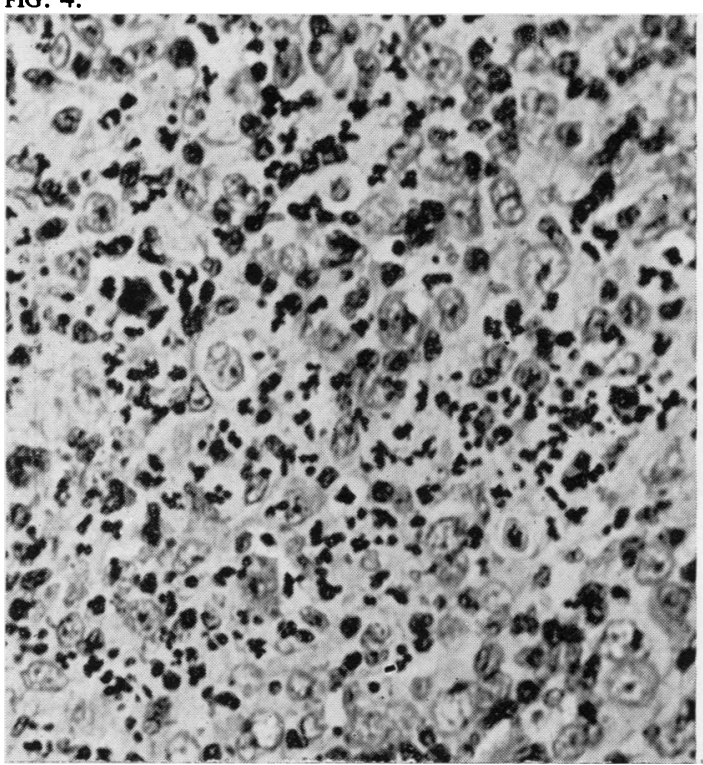

FIG. 5 .

FIG. 3A. Dense fibrosis around blood vessel in nodular sclerosis (haematoxylin and eosin $\times 100$ ).

B Characteristic nodule found in nodular sclerosis with abnormal lymphoid tissue surrounded by bands of dense fibrous tissue (haematoxylin and eosin $\times 25$ ).

FIG. 4. Biopsy from a patient with nodular sclerosis in the early stages showing slight thickening of capsule, loss of normal follicular pattern, and suggestion of nodular arrangement (haematoxylin and eosin $\times 100$ ).

FIG. 5. Nodular sclerosis showing foci of necrosis with degenerate polymorphs and abnormal reticulum cells (haematoxylin and eosin $\times 400$ ). 


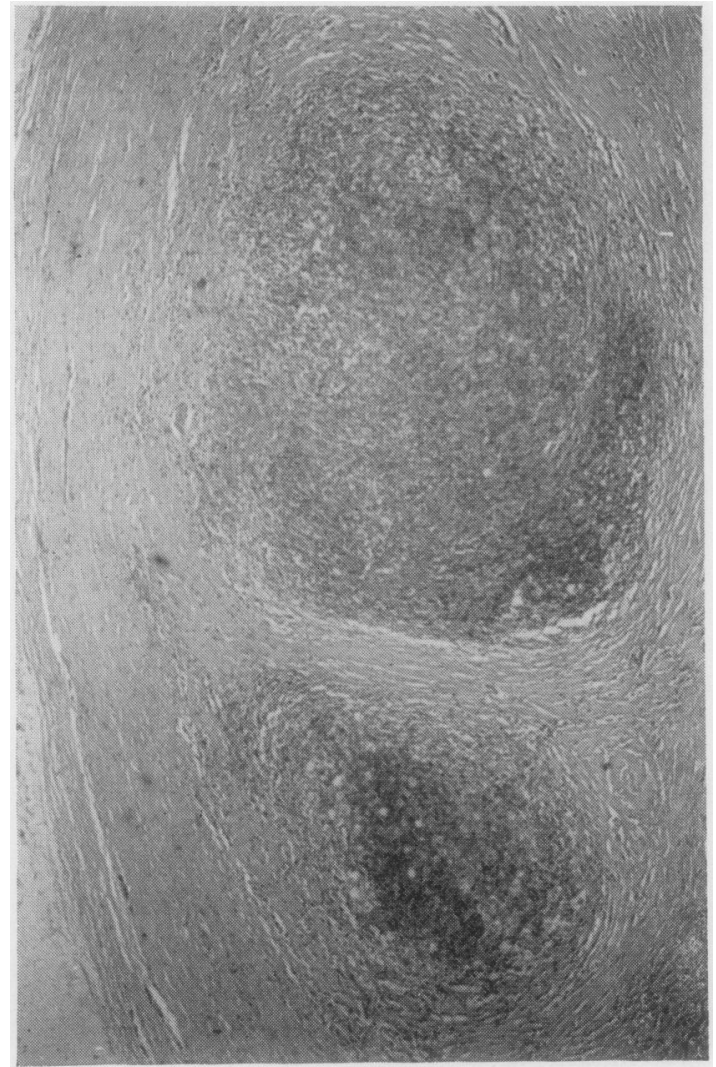

FIG. 6A.

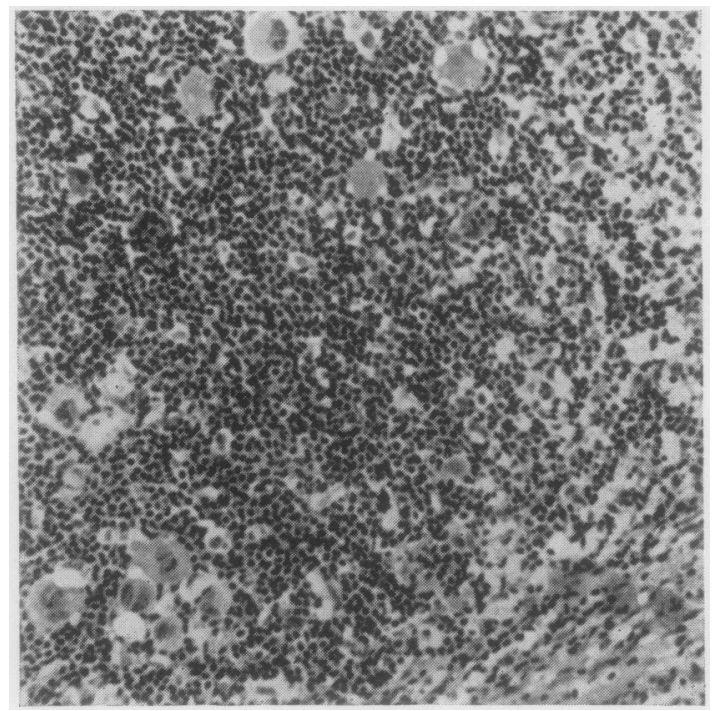

FIG. 6B.

FIG. 6. Nodular sclerosis, well differentiated type.

A Capsule is markedly thickened, nodular pattern well developed (haematoxylin and eosin $\times 25$ ).

B The preponderant cell is the lymphocyte (haematoxylin and eosin $\times 100$ ).
WELL DIFFERENTIATED NODULAR SCLEROSING HODGKIN'S DISEASE The nodular pattern was present in only one part of a lymph gland or was fully developed. The preponderant cell both inside and outside the nodules was the normal lymphocyte. Only a few mirror-image binucleate Sternberg-Reed cells were seen but, in addition to the cells regarded as specific for nodular sclerosis, there were other abnormal reticulum cells which were moderately pleomorphic. The majority had a single-lobed nucleus varying in size from 20 to $40 \mu$; the nuclear membrane was thickened, the chromatin pattern was fine, and the nucleolus was small. Eosinophils and plasma cells were present in moderate numbers in all glands and focal areas of necrosis were found in 10 instances (Fig. 5). Well differentiated nodular sclerosis was diagnosed in 21 patients (Fig. 6).

POORLY DIFFERENTIATED NODULAR SCLEROSING HODGKIN'S DISEASE A nodular pattern was seen in all the lymph glands diagnosed as poorly differentiated but irregular sheets of fibrosis were also always present. The number of lymphocytes was greatly reduced and the cellular pattern was composed mainly of abnormal reticulum cells. The cells with multilobed nuclei typical of nodular sclerosis were present but Sternberg-Reed cells were more numerous and other more pleomorphic abnormal reticulum cells were also seen. The chromatin pattern in these was dense and arranged in irregular clumps and a large eosinophilic nucleolus was present. Focal areas of necrosis were present in all glands.

Eight patients were classified as cases of poorly differentiated nodular sclerosis (Figs. 7A and B).

Either the well differentiated or the poorly differentiated form was seen in the lymph gland biopsy at initial presentation; in the four patients on whom multiple biopsies were carried out there was a progression from the well differentiated to the poorly differentiated pattern.

\section{CLINICAL FEATURES}

The ages of the 29 patients on first examination ranged from 18 to 47 (median 23 years); 24 were males, five were females $(4.8$ to 1$)$ compared with the sex incidence in the remainder of the 213 Hodgkin's disease patients of 200 males to 13 females (15.4 to 1). The distribution of enlarged glands on presentation is shown in Table I. Each patient showed a variable clinical course; periods of remission which ranged from several months up to one to two years were common after treatment and in one instance the remission lasted 15 years (Table II). Exacerbations were characterized by enlarge- 


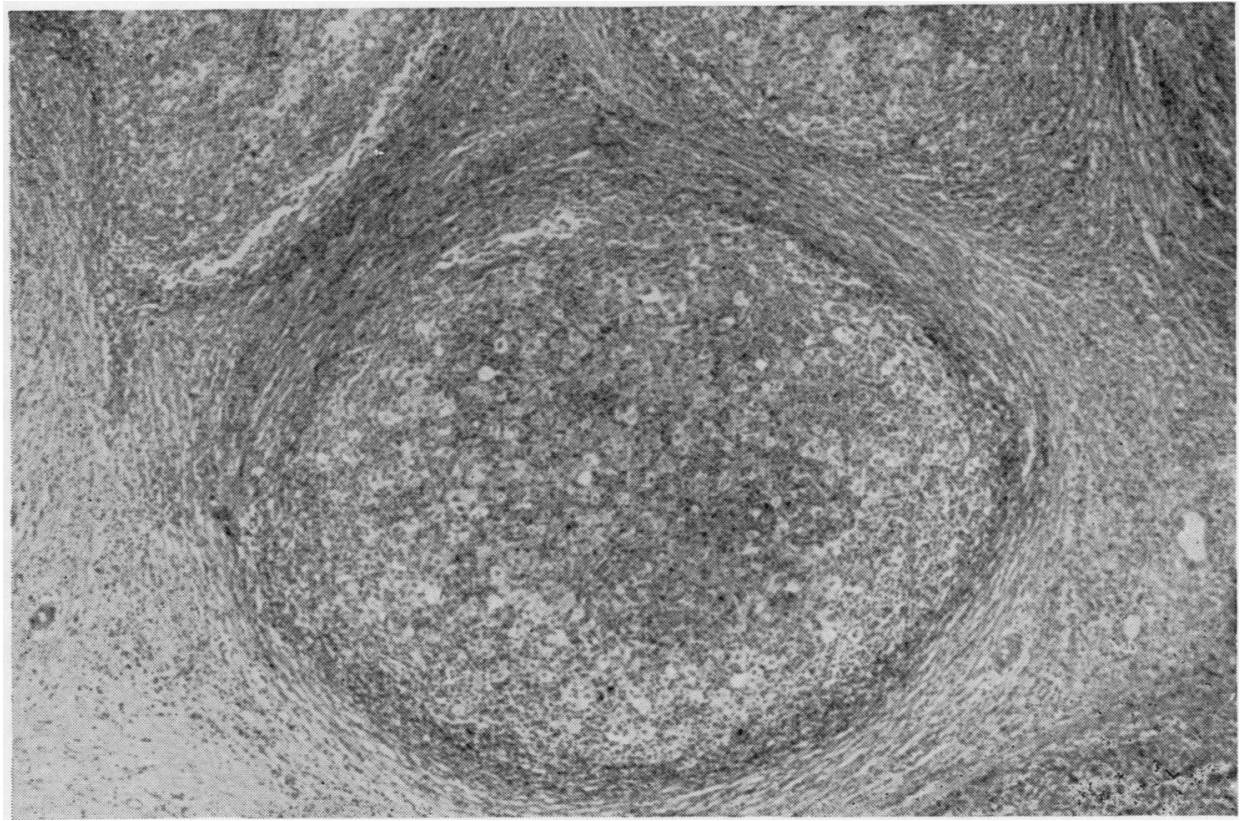

FIG. 7A.

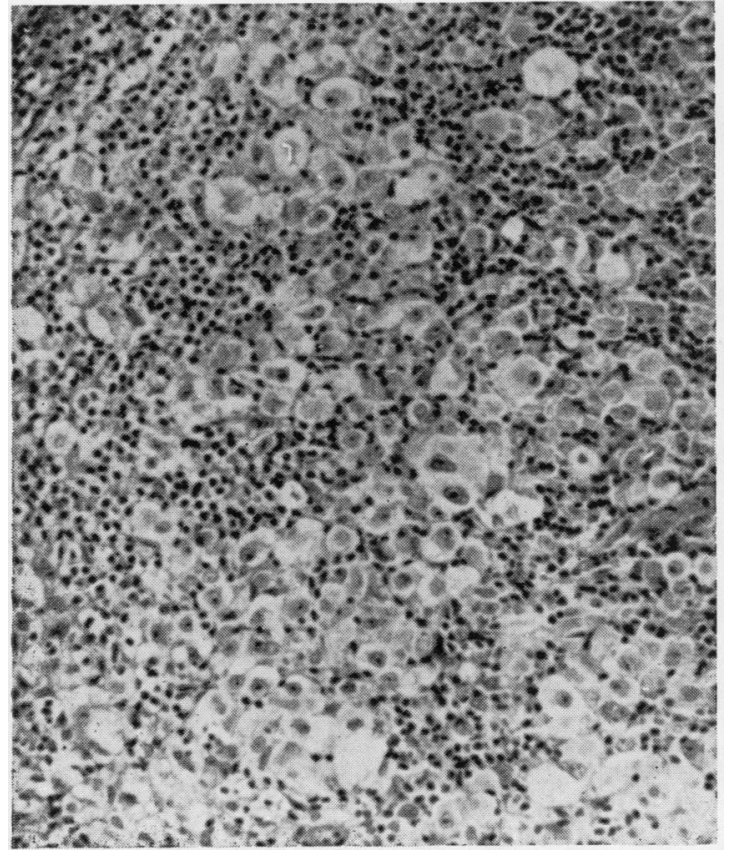

FIG. 7B.

FIG. 7. Nodular sclerosis of poorly differentiated type.

A Nodular pattern is well developed (haematoxylin and eosin $\times 25$ ).

B The preponderant cell is the abnormal reticulum cell (haematoxylin and eosin $\times 100$ ). ment of any groups of glands. As examples of the variation in clinical state, it was noted that 15 patients had anaemia severe enough to require blood transfusions; 13 had lymphomatous deposits in the spine; on the other hand, two patients achieved successful pregnancies, one of them on two occasions, during the course of the disease.

In most instances $x$-ray therapy was used alone as the initial treatment. As the disease progressed either deep $x$-rays, cytotoxins, or a combination of both were used. In the later stages treatment was usually confined to cytotoxins.

\section{TABLE I}

DISTRIBUTION OF ENLARGED GLANDS ON PRESENTATION IN NODULAR SCLEROSING HODGKIN'S DISEASE

\begin{tabular}{lr} 
Region Involved & Number of \\
\hline Cervical & 6 \\
Cervical + axilla & 3 \\
Cervical + mediastinum & 7 \\
Cervical + inguinal & 1 \\
Cervical + axilla + mediastinum & 7 \\
Cervical + mediastinum + inguinal & 3 \\
Axilla + mediastinum & 1 \\
Inguinal & 1 \\
Total & 29
\end{tabular}

SURVIVAL

The two, five, 10, and 15-year survival times of these 29 patients are shown in Table III and are compared with patients with paragranuloma from the same 


\section{TABLE II}

WELL DIFFERENTIATED NODULAR SCLEROSIS SHOWING SURVIVAL TIME AND NUMBER OF RELAPSES DURING THE ILLNESS

\begin{tabular}{|c|c|c|c|}
\hline Case No. & Survival Time & Number of & Relapses \\
\hline 9 & $6 \mathrm{yr} 11 \mathrm{mth}$ & 16 & $\mathbf{A}$ \\
\hline 21 & $9 \mathrm{yr} 1 \mathrm{mth}$ & Nil & \\
\hline 26 & $7 \mathrm{yr} 9 \mathrm{mth}$ & 12 & $\mathbf{A}$ \\
\hline 34 & $6 \mathrm{yr} 5 \mathrm{mth}$ & 9 & $\mathbf{A}$ \\
\hline 47 & $10 \mathrm{yr} 3 \mathrm{mth}$ & 4 & \\
\hline 51 & $7 \mathrm{yr} 5 \mathrm{mth}$ & 3 & \\
\hline 64 & $12 \mathrm{yr} 2 \mathrm{mth}$ & 18 & \\
\hline 70 & $4 \mathrm{yr}$ & 6 & \\
\hline 88 & $10 \mathrm{yr}$ & 4 & \\
\hline 110 & $7 \mathrm{yr} 7 \mathrm{mth}$ & 9 & \\
\hline 116 & $9 \mathrm{yr} 4 \mathrm{mth}$ & 3 & \\
\hline 123 & $4 \mathrm{yr} 6 \mathrm{mth}$ & 3 & \\
\hline 134 & $11 \mathrm{yr} 2 \mathrm{mth}$ & 8 & $\mathbf{A}$ \\
\hline 142 & 15 yr $5 \mathrm{mth}$ & 14 & \\
\hline 162 & $4 \mathrm{yr} 3 \mathrm{mth}$ & 12 & \\
\hline 179 & $18 \mathrm{yr}$ & 1 & \\
\hline 189 & $21 \mathrm{yr}$ & 11 & $\mathbf{A}$ \\
\hline 193 & 8 yr $3 \mathrm{mth}$ & 15 & \\
\hline 231 & $6 \mathrm{yr}$ & 7 & \\
\hline 271 & $15 \mathrm{yr} 5 \mathrm{mth}$ & 14 & \\
\hline 425 & $3 \mathrm{yr} 3 \mathrm{mth}$ & 7 & \\
\hline
\end{tabular}

$A=$ Alive at time of writing. series (Table III). The survival times of the patients related to the clinical staging proposed by Peters? and Middlemiss (1958) are shown in Table IV. The $\overrightarrow{\vec{F}}$ median survival time of 21 patients with well differentiated nodular sclerosis was eight years three months (range three years three months to 21 years) compared with 11 years (range five years two months ${ }_{\overparen{D}}$ to 20 years) in 20 instances of paragranuloma. Included in these figures are five patients with nodular sclerosis and seven patients with para- $\overrightarrow{0}$ granuloma who were alive at time of writing. The comparable median survival times of the patients $\vec{\omega}$ who died, however, showed little change, eight $\frac{}{2}$ years six months in nodular sclerosis and 10 years in? paragranuloma. The median survival time of the $-\overrightarrow{+}$ eight patients with poorly differentiated nodularis sclerosis was $2 \cdot 2$ years (range one year one month $\omega$ to three years).

Post-mortem examinations were carried out on $15^{\circ}$ of the fatalities and no contributory causes of death $\bar{Z}$ other than Hodgkin's disease were established. In the remaining nine cases there was similarly no-

TABLE III

SURVIVAL TIMES OF PATIENTS WITH NODULAR SCLEROSIS COMPARED WITH PARAGRANULOMA AT TWO, FIVE, 10, AND 15 YEARS

\begin{tabular}{|c|c|c|c|c|c|c|c|c|c|c|}
\hline \multirow[b]{2}{*}{$\begin{array}{l}\text { Type of } \\
\text { Hodgkin's Disease }\end{array}$} & \multirow[b]{2}{*}{$\begin{array}{l}\text { Total } \\
\text { Number }\end{array}$} & \multirow[b]{2}{*}{$\begin{array}{l}\text { Number } \\
\text { Dead }\end{array}$} & \multicolumn{2}{|c|}{ Two-year Survival } & \multicolumn{2}{|c|}{ Five-year Survival } & \multicolumn{2}{|c|}{ 10-year Survival } & \multicolumn{2}{|c|}{ 15-year Survival } \\
\hline & & & $\begin{array}{l}\text { Follow-up } \\
\text { Survival }\end{array}$ & $\begin{array}{l}\text { Number } \\
\text { Surviving } \\
\text { Two Years }\end{array}$ & $\begin{array}{l}\text { Follow-up } \\
\text { Survival }\end{array}$ & $\begin{array}{l}\text { Number } \\
\text { Surviving } \\
\text { Five Years }\end{array}$ & $\begin{array}{l}\text { Follow-up } \\
\text { Survival }\end{array}$ & $\begin{array}{l}\text { Number } \\
\text { Surviving } \\
10 \text { Years }\end{array}$ & $\begin{array}{l}\text { Follow-up } \\
\text { Survival }\end{array}$ & $\begin{array}{l}\text { Number } \\
\text { Surviving } \\
15 \text { Years }\end{array}$ \\
\hline $\begin{array}{l}\text { Paragranuloma } \\
\text { Nodular sclerosis }\end{array}$ & 20 & 8 & 20 & $20(100 \%)$ & 20 & $20(100 \%)$ & 16 & $11(69 \%)$ & 10 & $2(20 \%)$ \\
\hline $\begin{array}{l}\text { Well differentiated } \\
\text { Poorly differentiated }\end{array}$ & $\begin{array}{r}21 \\
8\end{array}$ & $\begin{array}{r}16 \\
8\end{array}$ & $\begin{array}{r}21 \\
8\end{array}$ & $\begin{array}{c}21(100 \%) \\
7(87 \%)\end{array}$ & $\begin{array}{r}21 \\
8\end{array}$ & $\begin{array}{l}17(81 \%) \\
\text { Nil }\end{array}$ & $\begin{array}{r}18 \\
8\end{array}$ & $\begin{array}{l}8(44 \%) \\
\text { Nil }\end{array}$ & $\begin{array}{r}18 \\
8\end{array}$ & $\begin{array}{l}4(22 \%) \\
\text { Nil }\end{array}$ \\
\hline
\end{tabular}

TABLE IV

RELATIONSHIP OF CLINICAL STAGING TO MEDIAN SURVIVAL TIME USING THE CLASSIFICATION OF PETERS AND MIDDLEMISSO (1950)

\begin{tabular}{|c|c|c|c|c|c|c|c|c|c|}
\hline \multirow[b]{2}{*}{ Author } & \multirow[b]{2}{*}{$\begin{array}{l}\text { Type of Hodgkin's } \\
\text { Disease }\end{array}$} & \multicolumn{2}{|l|}{ Stage I } & \multicolumn{2}{|c|}{ Stage II } & \multicolumn{2}{|c|}{ Stage III } & \multicolumn{2}{|c|}{ All Stages } \\
\hline & & $\begin{array}{l}\text { No. of } \\
\text { Cases }\end{array}$ & $\begin{array}{l}\text { Median } \\
\text { Survival } \\
\text { Time }\end{array}$ & $\begin{array}{l}\text { No. of } \\
\text { Cases }\end{array}$ & $\begin{array}{l}\text { Median } \\
\text { Survival } \\
\text { Time }\end{array}$ & $\begin{array}{l}\text { No. of } \\
\text { Cases }\end{array}$ & $\begin{array}{l}\text { Median } \\
\text { Survival } \\
\text { Time }\end{array}$ & $\begin{array}{l}\text { No. of } \\
\text { Cases }\end{array}$ & $\begin{array}{l}\text { Median } \\
\text { Survival } \\
\text { Time }\end{array}$ \\
\hline $\begin{array}{l}\text { Lukes (1963) } \\
\text { Hanson (1964) }\end{array}$ & $\begin{array}{l}\text { Nodular sclerosis } \\
\text { Nodular sclerosis }\end{array}$ & $\begin{array}{r}53 \\
5\end{array}$ & $\begin{array}{l}11 \cdot 0 \mathrm{yr} \\
\text { Not recorded } \\
\text { Best } \\
10 \mathrm{yr} \text { survival } \\
3\end{array}$ & $\begin{array}{l}54 \\
19\end{array}$ & $\begin{array}{l}3 \cdot 2 \mathrm{yr} \\
\text { Not recorded } \\
10 \mathrm{yr} \text { survival } \\
4\end{array}$ & $\begin{array}{l}42 \\
13\end{array}$ & $\begin{array}{l}1 \cdot 8 \mathrm{yr} \\
\text { Not recorded } \\
10 \mathrm{yr} \text { survival } \\
2\end{array}$ & $\begin{array}{r}149 \\
27\end{array}$ & $\begin{array}{l}4 \cdot 2 \mathrm{yr} \\
\text { Not recordor }\end{array}$ \\
\hline Present Series & $\begin{array}{l}\text { Nodular sclerosis } \\
\text { well differentiated } \\
\text { Nodular sclerosis } \\
\text { poorly differentiated }\end{array}$ & $\begin{array}{l}3 \\
3\end{array}$ & $\begin{array}{l}9 \cdot 1 \mathrm{yr}^{1} \\
2 \cdot 1 \mathrm{yr}\end{array}$ & $\begin{array}{r}14 \\
5\end{array}$ & $\begin{array}{l}8.8 \mathrm{yr}^{2} \\
2.5 \mathrm{yr}\end{array}$ & $\begin{array}{c}4 \\
\text { Nil }\end{array}$ & $7 \cdot 1 \mathrm{yr}^{3}$ & $\begin{array}{r}21 \\
8\end{array}$ & $\begin{array}{l}8.3 \mathrm{yr} \\
2.2 \mathrm{yr}\end{array}$ \\
\hline $\begin{array}{l}\text { 1One patient in } \\
\text { 2Two patients i } \\
\text { 'Two patients i }\end{array}$ & $\begin{array}{l}\text { stage I alive (not activ } \\
\text { n stage II alive (both a } \\
\text { n stage III alive (both }\end{array}$ & & & & & & & & \\
\hline
\end{tabular}


clinical evidence of extraneous factors involved in the death.

\section{DISCUSSION}

The clinical course in nodular sclerosis appeared to be different from that seen in other types of Hodgkin's disease. Lukes (1963) suggested that the longer survival times were due to the fact that in some patients the disease was localized and remained quiescent for many years. This, however, does not appear to be applicable to the well differentiated type of nodular sclerosis as defined in the present series, since the patients relapsed on several occasions during the course of the illness (Table II); the same group of glands frequently again became enlarged on several occasions but application of radiotherapy or cytotoxins relieved the condition and the patients remained well until the next relapse. In contrast, if the patients with paragranuloma, whom we have studied, relapsed, the illness was generally mild and usually they remained completely well for many years before the final progressive stage of the disease was reached.

Hanson (1964) discussed the difference between the incidence of nodular sclerosis in his series and those reported by Lukes (1963). Among the 377 patients described by Lukes as having Hodgkin's disease there were only seven females, and 149 $(40 \%)$ were classified as nodular sclerosis; Hanson, on the other hand, described 251 patients with Hodgkin's disease and found that 22 of 37 patients with nodular sclerosis were females, a sex ratio of 1.5 females to 1 male. If this ratio was applied as a correction factor to Lukes' series it would result in an even higher percentage of cases of nodular sclerosis in a balanced population than that reported. The present series of 242 patients with Hodgkin's disease contained $12.6 \%$ with nodular sclerosis, but inevitably showed a preponderance of males since it was drawn from patients seen in Royal Air Force hospitals. Here the expected incidence of nodular sclerosis in a balanced population would probably be in the region of $15 \%$ of cases of Hodgkin's disease which is similar to the findings of Hanson (1964) and Harrison (1966).

A possible explanation of the discrepancies in incidence between that reported by Lukes (1963) and other authors may lie in differences in histological interpretation. Smetana and Cohen (1956), who examined virtually the same material as Lukes, found only $18.5 \%$ of sclerosing types. As the latter author put considerable emphasis on the demonstration of birefringent collagen as a diagnostic criterion, it is possible that his numbers of cases of nodular sclerosis would have been lower if he had applied more stringent criteria to the cytological features in the affected glands.

The recognition of the reticulum cell with its multilobed nucleus, which appears to be typical of nodular sclerosis, is important histologically for two reasons. First, it may indicate the diagnosis before the typical fibrous pattern has been established. Secondly, it helps to differentiate nodular sclerosis in its developed form from the poorly differentiated form of other types of Hodgkin's disease; although the latter may show extensive areas of collagenous fibrosis with pockets of eosinophils and plasma cells, the large multilobed abnormal reticulum cells are not seen.

Within the group of patients who can be accurately diagnosed on histological grounds as having nodular sclerosis, the majority have a good prognosis but there are some who do not survive more than two years. In contrast to Lukes (1963), who found $36 \%$ of patients with nodular sclerosis presenting as stage I disease, Hanson reported $14 \%$, and in the present series only $12 \%$ were found. In spite of this, the median survival time in the well differentiated type of nodular sclerosis in this series was nine years one month (Table IV).

A breakdown of the number of regions involved at onset (Table V) indicates that long survival time does not depend on having stage I disease, and, in

TABLE V

NUMBER OF GLAND REGIONS INVOLVED AT PRESENTATION CORRELATED WITH SURVIVAL TIME IN WELL DIFFERENTIATED AND POORLY DIFFERENTIATED NODULAR SCLEROSIS

\begin{tabular}{|c|c|c|c|c|}
\hline Nodular Sclerosis & Number of Regions & Number of Cases & Median Survival Time & Range \\
\hline Well differentiated & $\begin{array}{l}1 \\
2 \\
3 \\
4 \\
5\end{array}$ & $\begin{array}{l}3 \\
4 \\
6 \\
5 \\
3\end{array}$ & $\begin{array}{r}9 \mathrm{yr} 1 \mathrm{mth} \\
11 \mathrm{yr} 1 \mathrm{mth} \\
8 \mathrm{yr} 4 \mathrm{mth} \\
6 \mathrm{yr} 11 \mathrm{mth} \\
8 \mathrm{yr} 3 \mathrm{mth}\end{array}$ & $\begin{array}{l}3 \mathrm{yr} 5 \mathrm{mth} \text { to } 18 \mathrm{yr} \\
7 \mathrm{yr} 7 \mathrm{mth} \text { to } 15 \mathrm{yr} 5 \mathrm{mth} \\
4 \mathrm{yr} \text { to } 21 \mathrm{yr} \\
4 \mathrm{yr} 6 \mathrm{mth} \text { to } 11 \mathrm{yr} 2 \mathrm{mth} \\
3 \mathrm{yr} 3 \mathrm{mth} \text { to } 9 \mathrm{yr} 4 \mathrm{mth}\end{array}$ \\
\hline Poorly differentiated & $\begin{array}{l}1 \\
2 \\
3\end{array}$ & $\begin{array}{l}3 \\
3 \\
2\end{array}$ & 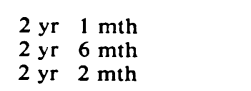 & $\begin{array}{l}2 \mathrm{yr} \text { to } 2 \mathrm{yr} 2 \mathrm{mth} \\
1 \mathrm{yr} 6 \mathrm{mth} \text { to } 3 \mathrm{yr} 1 \mathrm{mth} \\
2 \mathrm{yr} \text { to } 2 \mathrm{yr} 5 \mathrm{mth}\end{array}$ \\
\hline
\end{tabular}


fact, the figures suggest that the clinical staging of Peters and Middlemiss (1958) is of little prognostic significance in this type of disease.

The use of lymphocytic depletion and the degree of anaplasia of the abnormal reticulum cells gives an arbitrary separation into well differentiated and poorly differentiated types, indicating a good or bad prognosis. These two groups of patients therefore are better distinguished on histological rather than clinical grounds.

With regard to the site of involvement on presentation, both Lukes (1963) and Hanson (1964) suggested that nodular sclerosis was typically located in the mediastinum. Despite the observation that none of the patients in his series presented with enlarged glands below the diaphragm, Hanson (1964) recorded five patients in stage I, 19 in stage II, and 13 in stage III. It is difficult to understand this observation, as stage III is enlargement of glands both above and below the diaphragm. The incidence of mediastinal involvement at onset $(60 \%)$ reported here is certainly high compared with other types of Hodgkin's disease $(27 \%)$ and is similar to the findings of both Lukes and Hanson. However, in no patient was the lymphadenopathy, at onset, confined solely to the mediastinum. Cervical gland enlargement was present in $27(93 \%)$ of the patients and in addition five $(17 \%)$ presented with involved inguina: glands: it would seem, therefore, that the concept of nodular sclerosis as a regional manifestation of Hodgkin's disease cannot be sustained on the find $\stackrel{\text { ? }}{-}$

ings reported here.

There now. seems little doubt that nodular sclero $\frac{\text { ㅁ }}{\omega}$ sing Hodgkin's disease is a recognizable variant and that its recognition is important as it may share with paragranuloma the most favourable prognosise of any form of Hodgkin's disease.

I wish to thank Air Vice Marshal Sir Peter Dixon for $\vec{\omega}$ his cooperation in this lymphoma study; Air Vice? Marshal W. P. Stamm and Squadron Leader A. W용 McCracken for their help in the preparation of the paper,j and the Director General of Medical Services, Royal Air $\overrightarrow{{ }_{0}}$ Force, for permission to publish. My thanks are especially due to Flight Sergeant $P$. Mulhall and the histology technicians at IPTM Halton for their technical assistance.

\section{REFERENCES}

Hanson, T. A. S. (1964). Cancer (Philad.), 17, 1595. Harrison, C. V.(1966). Recent Advances in Pathology, 8th ed. Churchill London.

Jackson, H., Jnr., and Parker, F., Jnr. (1947). Hodgkin's Disease and Allied Disorders, Oxford University Press, New York.

Lukes, R. J. (1963). Amer. J. Roent genol., 90, 944.

Peters, M. V., and Middlemiss, K. C. H. (1950). Ibid., 63, 299.

Smetana, H. F., and Cohen, B. M. (1956). Blood, 11, 211. 